\title{
Streptomyces durmitorensis sp. nov., a producer of an FK506-like immunosuppressant
}

Correspondence

Branka Vasiljevic vasiljb@eunet.yu
Miloje Savic,† Ivana Braticł and Branka Vasiljevic

Institute of Molecular Genetics and Genetic Engineering, Vojvode Stepe 444a, PO Box 23, 11010 Belgrade, Serbia

\begin{abstract}
Screening of soil samples from the Durmitor National Park, Serbia and Montenegro, for strains producing immunosuppressants with a similar mechanism of action to FK506 resulted in the isolation of the actinomycete strain $\mathrm{MS}_{405^{\top}}$. Isolate $\mathrm{MS} 405^{\top}$ was found to have morphological and phenotypic properties that were consistent with its classification as a Streptomyces strain.

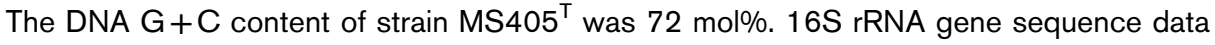
confirmed the taxonomic position of the strain, following the generation of phylogenetic trees by using various treeing algorithms. On the basis of $16 \mathrm{~S}$ rRNA gene sequence similarity, strain MS405 ${ }^{\top}$ was shown to belong to the Streptomyces albidoflavus 'supercluster', being related to Streptomyces aureus DSM $41785^{\top}$ ( $99.59 \%$ similarity) and Streptomyces kanamyceticus DSM $40500^{\top}$ (99.32\%). The 16S-23S rRNA internally transcribed spacer (ITS) region exhibited variations in length and sequence composition, showing limited usefulness in phylogenetic analyses. However, DNA relatedness values support the classification of this isolate within a novel species. A number of physiological and biochemical tests distinguished strain $M S 405^{\top}$ from its closest phylogenetic neighbours. Therefore, strain $M S 405^{\top}$ represents a novel species, for which the name Streptomyces durmitorensis sp. nov. is proposed, with the type strain MS405 ${ }^{\top}$ (=DSM $41863^{\top}=\operatorname{CIP} 108995^{\top}$ ).
\end{abstract}

Actinomycetes are distributed in terrestrial environments and have been a source of useful bioactive molecules. By conventional isolation methods, members of the genus Streptomyces comprise more than $95 \%$ of the filamentous actinomycete population of soil (Elander, 1987). Therefore, an organized taxonomic system to identify novel strains is needed in order to preclude reisolation of already known species. The $16 \mathrm{~S}$ rRNA gene sequence is highly conserved within living cells and has been widely used for evolutionary studies in bacteria (Woese, 1987), placing organisms in the framework of phylogenetic relationships (Stackebrandt et al., 1997). However, $16 \mathrm{~S}$ rRNA gene

tPresent address: Faculty of Life Sciences, University of Manchester, Manchester Interdisciplinary Biocentre, 131 Princess Street, Manchester M1 7DN, UK.

‡Present address: Division of Metabolic Diseases, Department of Laboratory Medicine, Karolinska Institute, Novum, SE-14186 Stockholm, Sweden

Abbreviations: DAP, diaminopimelic acid; ITS, internally transcribed spacer.

The GenBank/EMBL/DDBJ accession numbers for the 16S rRNA gene

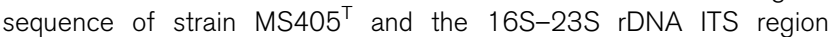

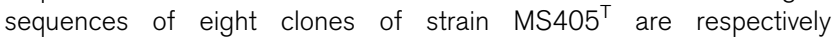
DQ067287 and DQ067288-DQ067295.

Sequences of ITS variable regions in strain $M S 405^{\top}$ and electron micrographs of the strain are available as supplementary material with the online version of this paper. sequences may be insufficient to define phylogenetic relationships among closely related species and among strains belonging to a species because of evolutionary conservation of the 16S rRNA gene (Woese, 1987). It has been suggested that the 16S-23S rRNA internally transcribed spacer (ITS) region is a powerful tool for phylogenetic analysis of Gram-negative bacteria, but not of Gram-positive bacteria, especially Streptomyces species (Gurtler \& Stanisich, 1996; Hain et al., 1997; Song et al., 2004). To overcome these problems, it has now become common practice to delineate novel Streptomyces species using a combination of genotypic and phenotypic data (Kim et al., 1998, 2000; Sembiring et al., 2000) in a socalled polyphasic taxonomic study, which is expected to lead to well-described species and a stable nomenclature (Goodfellow et al., 1997).

Actinomycete strain $\mathrm{MS} 405^{\mathrm{T}}$ was isolated by a serial dilution method (http://www.bio.com/protocolstools/protocol.jhtml?id=p2181) from soil samples collected at the Durmitor National Park, Serbia and Montenegro, as a producer of a secondary metabolite exhibiting an FK506like immunosuppressant mechanism of action (Skoko et al., 2005). The taxonomic status of strain $\mathrm{MS} 405^{\mathrm{T}}$ was investigated using a combination of phenotypic and molecular systematic means, which were indispensable in placing strain $\mathrm{MS} 45^{\mathrm{T}}$ within the genus Streptomyces. Polyphasic study of strain MS405 ${ }^{\mathrm{T}}$ showed that this strain 
should be formally recognized as representing a novel species of the genus Streptomyces.

To investigate the phylogenetic relationships of strain $\mathrm{MS}_{405}{ }^{\mathrm{T}}$, its almost-complete $16 \mathrm{~S}$ rRNA gene sequence (1517 nt) was determined. Bacterial DNA was extracted by a method described previously (Hopwood et al., 1985). The extracted DNA was subjected to PCR amplification with the bacteria-specific 16S rRNA primers 27f (Lane, 1991) and 1392rev (Marchesi et al., 1998). PCR amplification was performed as described by Marchesi et al. (1998). The 16S23S ITS region, including the $3^{\prime}$ end of the 16S rRNA gene, was amplified by PCR using primers AM45 (Mehling et al., 1995) and L1 (Jensen et al., 1993). PCR products were excised from the gel and purified using a QIAEXII gel extraction kit (Qiagen) according to the manufacturer's instructions. The purified product was then ligated to pMOSBlue vector according to the manufacturer's instructions (Amersham Pharmacia Biotech). Recombinant plasmid constructs were isolated using Qiagen minicolumns (QIAprep Spin Miniprep kit) and sequenced on an ALF Express sequencer using a Cy5-AutoRead kit (Amersham Biosciences) and the universal sequencing primers M13f and M13r.

$16 \mathrm{~S}$ rRNA gene sequence analysis was conducted using the BLAST network services provided by the NCBI (Altschul et al., 1997) and the Ribosomal Database Project (RDP; http://rdp.cme.msu.edu) (Maidak et al., 2001). Alignment was performed with the CLUSTAL $\mathrm{W}$ program (Thompson et al., 1994). 16S rRNA gene sequences and 16S-23S ITS sequences were aligned against published sequences available in the DDBJ/GenBank/EMBL databases by the $\mathrm{K}_{\text {nuc }}$ value of Kimura (1980), and phylogenetic trees were constructed by the neighbour-joining (Saitou \& Nei, 1987) and maximum-parsimony (Fitch, 1971; Felsenstein, 1993) algorithms contained in the PHYLIP package (version 3.5c; http://www.pasteur.fr). The topology of the phylogenetic tree was evaluated by the bootstrap resampling method of Felsenstein (1985) with 1000 replicates. 16S rRNA gene sequence similarities were calculated using the EMBOSS:needle (global) method available at http://www. ebi.ac.uk.

Phylogenetic analysis, at the RDP (Maidak et al., 2001), placed the strain within the evolutionary radiation encompassed by the genus Streptomyces, where the 16S rRNA gene sequence of Streptomyces aureus DSM $41785^{\mathrm{T}}$ was identified with the highest probability $(0.969)$ as the closest matching sequence to MS405 ${ }^{\mathrm{T}}$. The analysis was supported by the neighbour-joining (Saitou \& Nei, 1987) and maximumlikelihood (Felsenstein, 1993) methods. Comparing Streptomyces 16S rRNA gene sequences by phylogenetic tree algorithms, it was obvious that a subclade was formed (Fig. 1) containing sequences of Streptomyces seoulensis IMSNU $21266^{\mathrm{T}}$, S. aureus DSM $41785^{\mathrm{T}}$, Streptomyces kanamyceticus DSM $40500^{\mathrm{T}}$ and strain $\mathrm{MS} 405^{\mathrm{T}}$. Within this subclade, strain MS405 ${ }^{\mathrm{T}}$ formed a monophyletic line. This relationship was evident in evolutionary trees based on

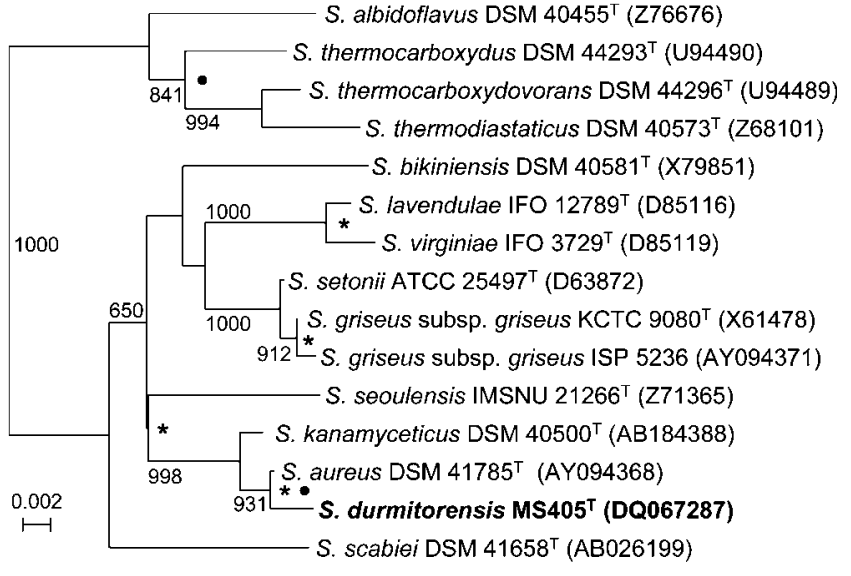

Fig. 1. Phylogenetic tree derived from $16 \mathrm{~S}$ rRNA gene sequences showing the relationship of strain $\mathrm{MS} 405^{\top}$ and related Streptomyces species. Asterisks indicate branches that were recovered using the maximum-parsimony algorithm (Fitch, 1971; Felsenstein, 1993); black dots indicate branches recovered using the maximum-likelihood (Felsenstein, 1993) and neighbour-joining (Saitou \& Nei, 1987) algorithms at the RDP server. The phylogenetic tree based on BIONJ algorithm (Gascuel, 1997) had the same topology as the tree shown here (data not shown). Numbers at nodes exhibit levels of bootstrap support based on neighbour-joining analyses of 1000 resampled datasets; only values above 600 are given. Accession numbers are given in parentheses. Bar, 0.002 nucleotide substitutions per position.

different treeing algorithms: neighbour-joining and DNADIST contained in the PHYLIP package (Felsenstein, 1993), the maximum-parsimony algorithm (Fitch, 1971; Felsenstein, 1993), the maximum-likelihood (Felsenstein, 1993) and BIONJ (Gascuel, 1997) (Fig. 1). The 16S rRNA gene sequence similarity values were 99.59 and $99.32 \%$ between strain $\mathrm{MS}_{405^{\mathrm{T}}}$ and $S$. aureus DSM $41785^{\mathrm{T}}$ and $S$. kanamyceticus DSM $40500^{\mathrm{T}}$, over 1448 and 1477 nucleotides compared, respectively.

The high degree of sequence divergence of the 16S-23S ITS region among streptomycetes has been shown to be of limited usefulness during phylogenetic positioning of strains (Song et al., 2004), though the utility of this region for inferring phylogenetic relationships has been demonstrated for Streptomyces albidoflavus strains (Hain et al., 1997). Sequencing of the 16S-23S ITS region of strain $M S 405^{\mathrm{T}}$, from eight randomly selected clones, revealed length and sequence composition heterogeneity. The analysed sequences were 283 to $303 \mathrm{nt}$ in length. Within the sequenced spacer regions, five variable regions and six conserved regions were identified. Highly conserved regions $\mathrm{C} 1$ to $\mathrm{C} 6$ were respectively $14,99,12,11,9$ and 53 nucleotides long. For each of the variable regions V1V5, more than one sequence was found (see Supplementary Table S1 in IJSEM Online). Consistent with previous observations for other streptomycetes, no tRNA-like sequences were found in any of the 16S-23S ITS regions. 
Phylogenetic analyses based on the 16S-23S ITS regions placed strain MS405 ${ }^{\mathrm{T}}$ close to Streptomyces scabiei isolate 87.79 (clone 79) (Fig. 2), showing the limited usefulness of the 16S-23S ITS region in inferring the phylogenetic position of strain $\mathrm{MS} 45^{\mathrm{T}}$. The branching of MS405 ${ }^{\mathrm{T}} 16 \mathrm{~S}-$ $23 S$ ITS sequences in two closely related clades is probably due to indel events contained within sequences ITS2, ITS4, ITS6 and ITS7 that are absent in the other four sequences.

DNA relatedness analysis was performed with strain MS405 ${ }^{\mathrm{T}}$ and the type strains S. aureus DSM $41785^{\mathrm{T}}$ and S. kanamyceticus DSM $40500^{\mathrm{T}}$ by the method of De Ley et al. (1970), under consideration of the modifications described by Huß et al. (1983), using a Cary 100 Bio UV/ Vis spectrophotometer equipped with a Peltier-thermostatted $6 \times 6$ multicell changer and a temperature controller with in situ temperature probe (Varian). Levels of DNA relatedness between strain MS405 ${ }^{\mathrm{T}}$ and the type strains of two closely related species (based on the phylogenetic data), S. aureus DSM $41785^{\mathrm{T}}$ and S. kanamyceticus DSM $40500^{\mathrm{T}}$, were respectively 15.5 and $13.3 \%$. These values clearly indicate that isolate MS405 ${ }^{\mathrm{T}}$ does not belong to the species $S$. aureus or S. kanamyceticus, as these values are well below the threshold value of $70 \%$ for definition of bacterial species according to Wayne et al. (1987). Additionally, DNA relatedness values below $80 \%$ have been recommended for the recognition of novel genomic species of Streptomyces (Labeda, 1993, 1996, 1998).

The morphological characteristics of strain $M S 405^{\mathrm{T}}$ were assessed by transmission (model CM12; Philips) and scanning (model JSM-6460; JEOL) electron microscopy of 14-day-old cultures grown on $\mathrm{NE}$ medium at $30{ }^{\circ} \mathrm{C}$ (Skeggs et al., 1985), following the procedure of O’Donnell

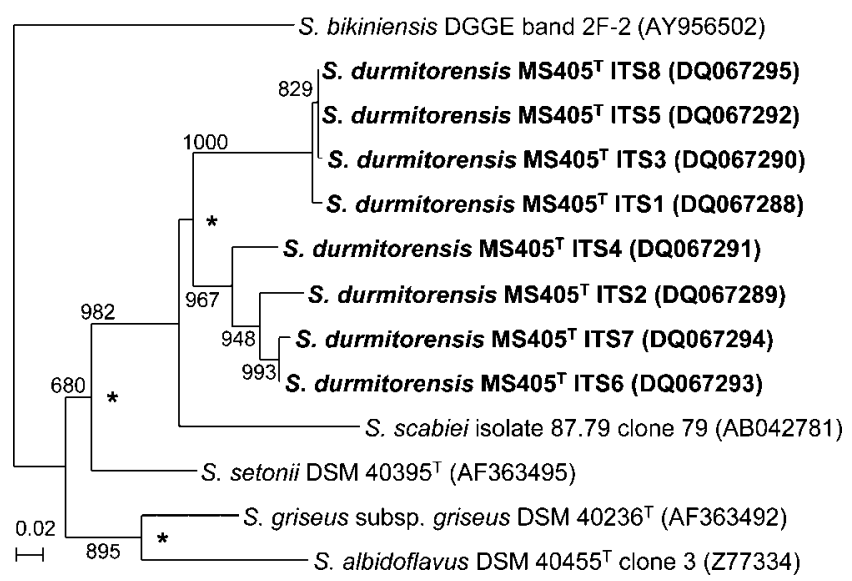

Fig. 2. Unrooted neighbour-joining tree based on 16S-23S ITS region sequences. Bootstrap values indicated at branching points were based on neighbour-joining analyses of 1000 resampled datasets (only values above 600 are shown). Asterisks indicate branches that were recovered using the maximum-parsimony algorithm. Accession numbers are given in parentheses. Bar, 0.02 nucleotide substitutions per position. et al. (1993). Cultural characteristics of strain $M S 405^{\mathrm{T}}$ were recorded after 14 days incubation according to the International Streptomyces Project (ISP) methods (Shirling \& Gottlieb, 1966). Colours were described according to the NBS-ISCC Color System (http://www.anthus.com).

Morphological observation of 14-day-old cultures grown on $\mathrm{NE}$ agar revealed aerial mycelium which consisted of straight chains of 10 or more rod-shaped, smooth-surfaced spores $(0.5-0.9 \times 1.0-1.5 \mu \mathrm{m})$ (Supplementary Fig. S1). The colour of the substrate mycelium was greenish grey on glycerolasparagine agar (ISP5), where no diffusible pigment was detected, and medium grey on inorganic salts-starch agar (ISP4). Melanin was not produced on peptone-yeast extractiron agar (ISP6) or tyrosine agar (ISP7) plates. Soluble darkgrey and dark-olive-green pigments were observed on ISP4 and NE, respectively. The phenotypic characteristics of strain $\mathrm{MS} 405^{\mathrm{T}}$ and phylogenetically related Streptomyces species are shown in Table 1. Biochemical, physiological and polymer degradation tests were performed as described previously (Seeley \& VanDemark 1981; Hopwood et al., 1985; Williams et al., 1983).

Sensitivity to antibiotics was tested by growing colonies on NE plates with linear antibiotic gradients ranging from 0 to $100 \mu \mathrm{g} \mathrm{ml}^{-1}$ for 7 days at $30{ }^{\circ} \mathrm{C}$. Detailed physiological and biochemical characteristics of strain $\mathrm{MS} 405^{\mathrm{T}}$ are given in the species description.

The isomer type of diaminopimelic acid (DAP) in the peptidoglycan layer was determined by hydrolysing cells with $6 \mathrm{M} \mathrm{HCl}$ at $100{ }^{\circ} \mathrm{C}$ for $18 \mathrm{~h}$ and analysed by TLC as described previously (Rhuland et al., 1955; Becker et al. 1965; Hasegawa et al., 1983), followed by ninhydrin staining $(0.1 \% \mathrm{w} / \mathrm{v}$ ninhydrin in acetone). Analysis showed that the cell wall contains LL-DAP, thereby indicating that strain

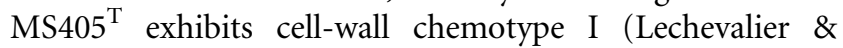
Lechevalier, 1970). Utilization of sugars or sugar alcohols as sole carbon sources was monitored in minimal medium containing M9 salts $\left(6 \mathrm{~g} \mathrm{Na}_{2} \mathrm{HPO}_{4}, 3 \mathrm{~g} \mathrm{~K}_{2} \mathrm{HPO}_{4}, 0.5 \mathrm{~g}\right.$ $\mathrm{NaCl}, 1 \mathrm{~g} \mathrm{NH}_{4} \mathrm{Cl}$ per litre, filter-sterilized) supplemented with $1 \mathrm{ml} 1 \mathrm{M} \mathrm{MgSO}_{4}, 1 \mathrm{ml} 0.1 \mathrm{M} \mathrm{CaCl}_{2}$ and $1 \%$ carbon source (w/v) (Miller, 1992). Plates were incubated for 7 days at $30{ }^{\circ} \mathrm{C}$. All media were adjusted to $\mathrm{pH} 7$ prior to seeding.

The chemical, morphological and phylogenetic data suggest that strain $M S 405^{\mathrm{T}}$ represents a novel species when compared with type strains of species with validly published names within the genus Streptomyces. Thus, on the basis of this polyphasic taxonomic study, strain $\mathrm{MS} 405^{\mathrm{T}}$ merits classification as the type strain of a novel species within the genus Streptomyces, and the name Streptomyces durmitorensis sp. nov. is proposed.

\section{Description of Streptomyces durmitorensis sp. nov.}

Streptomyces durmitorensis (dur.mi.tor.en'sis. N.L. masc. adj. durmitorensis pertaining to Durmitor, Serbia and Montenegro, where the type strain was isolated). 
Table 1. Phenotypic characteristics that differentiate strain $M S 405^{\top}$ from its closest neighbours

Strains: 1, MS405 $^{\mathrm{T}}$ (S. durmitorensis sp. nov.); 2, S. aureus DSM $41785^{\mathrm{T}}$ (data from Atalan et al., 2000; Manfio et al., 2003); 3, S. kanamyceticus DSM $40500^{\mathrm{T}}$ (Umezawa et al., 1957); 4, S. seoulensis IMSNU 21266 ${ }^{\mathrm{T}}$ (Chun et al., 1997). All strains are positive for growth on $1 \%$ (w/v) D- $(+)$-mannitol.

\begin{tabular}{|c|c|c|c|c|}
\hline Characteristic & 1 & 2 & 3 & 4 \\
\hline Colour of aerial spore mass on ISP5 & Greenish yellow & Grey & Colourless to yellow & Grey \\
\hline \multicolumn{5}{|l|}{ Colour of soluble pigment on: } \\
\hline ISP4 & Dark grey & Reddish orange & Faint brown & - \\
\hline ISP3 & - & Golden & Yellowish pink & - \\
\hline \multicolumn{5}{|l|}{ Growth on sole carbon sources $(1 \% \mathrm{w} / \mathrm{v})$} \\
\hline Dextran & + & - & - & - \\
\hline myo-Inositol & - & + & - & - \\
\hline D-Lactose & - & + & - & + \\
\hline \multicolumn{5}{|l|}{ Growth on sole nitrogen sources $(0.1 \% \mathrm{w} / \mathrm{v})$} \\
\hline L-Histidine & + & - & + & + \\
\hline L-Hydroxyproline & + & + & + & - \\
\hline Degradation of xanthine & + & + & + & - \\
\hline Nitrate reduction & + & + & + & - \\
\hline Maximum $\mathrm{NaCl}$ concentration for growth (\% w/v) & 9 & 7 & 7 & 7 \\
\hline Growth in the presence of thallous acetate $(0.001 \% \mathrm{w} / \mathrm{v})$ & + & + & - & - \\
\hline Antibiosis against Micrococcus luteus NCIMB 196 & + & - & + & - \\
\hline
\end{tabular}

Gram-positive, non-acid-fast streptomycete that produces a yellowish-grey and a greenish-grey substrate mycelium and a greenish-yellow aerial spore mass on yeast extract-malt extract and glycerol-asparagine agars. Soluble pigments are not formed on oatmeal, yeast extract-malt extract or glycerol-asparagine agars, while dark-grey pigment is formed on inorganic salts-starch agar. Melanoid pigments are not formed on peptone/yeast extract/iron or tyrosine agars. Spore chains are rectiflexibiles, with 10 or more rodshaped, smooth-surfaced spores $(0.5-0.9 \times 1.0-1.5 \mu \mathrm{m})$ per chain. Temperature range for growth is $10-37{ }^{\circ} \mathrm{C}$ with an optimum between 28 and $32{ }^{\circ} \mathrm{C}$. The cell wall contains LLDAP. Cellobiose, dextran, D- $(-)$-fructose, $\mathrm{D}-(+)$-galactose, D- $(+)$-glucose, glycerol, D- $(-)$-mannitol, D- $(+)$-mannose, $\alpha$-melibiose, $\mathrm{D}-(+)$-raffinose, $\mathrm{L}-(+)$-rhamnose, sucrose, $\alpha$ trehalose and $\mathrm{D}-(+)$-xylose are utilized for growth, but L$(+)$-arabinose, myo-inositol, $\alpha$-lactose, $\beta$-lactose, maltose and D-sorbitol are not utilized. Acid is produced from glucose. L-Alanine, L-arginine, L-cysteine, L-glycine, Lhistidine, L-hydroxyproline, L-methionine, L-proline and Lvaline are utilized as sole nitrogen sources, but L-asparagine, L-lysine, ornithine hydrochloride, L-phenylalanine and thiamine are not utilized. Nitrate is reduced to nitrite, gelatin is liquefied, xanthine is degraded, starch is not hydrolysed and aesculin and DNA are not degraded. Positive for nitrate reduction, catalase, extracellular protease, haemolysin ( $\beta$-haemolysis) and urease. Negative for lecithinase and $\mathrm{H}_{2} \mathrm{~S}$ and indole are not produced. Grows in the presence of $\mathrm{NaCl}(9 \%, \mathrm{w} / \mathrm{v})$ and thallous acetate $(0.001 \%$, w/v), but not sodium azide $(0.01 \%, \mathrm{w} / \mathrm{v})$, phenol $(0.1 \%$, w/v) or potassium tellurite $(0.001 \%, \mathrm{w} / \mathrm{v})$. Susceptible to apramycin $\left(10 \mu \mathrm{g} \mathrm{ml}^{-1}\right)$, kanamycin $\left(5 \mu \mathrm{g} \mathrm{ml}{ }^{-1}\right)$, gentamicin $(5 \mu \mathrm{g}$ $\left.\mathrm{ml}^{-1}\right)$, tetracycline $\left(10 \mu \mathrm{g} \mathrm{ml}^{-1}\right)$, thiostrepton $\left(10 \mu \mathrm{g} \mathrm{ml}^{-1}\right)$, chloramphenicol $\left(35 \mu \mathrm{g} \mathrm{ml}^{-1}\right)$ and spectinomycin $(90 \mu \mathrm{g}$ $\left.\mathrm{ml}^{-1}\right)$, but resistant to ampicillin $\left(100 \mu \mathrm{g} \mathrm{ml}^{-1}\right)$, erythromycin $\left(100 \mu \mathrm{g} \mathrm{ml}^{-1}\right)$ and FK506 $\left(100 \mu \mathrm{g} \mathrm{ml}^{-1}\right)$. The type strain, MS405 ${ }^{\mathrm{T}}$, produces an immunosuppressant with an FK506-like mechanism of action. The $\mathrm{G}+\mathrm{C}$ content of the DNA is $72 \mathrm{~mol} \%$. The type strain shows antimicrobial activity against Micrococcus luteus NCIMB 196 and Saccharomyces cerevisiae FAV 20, but not against Bacillus subtilis NCIMB $3610^{\mathrm{T}}$, Candida albicans CBS 562, Escherichia coli ATCC 25922, Pseudomonas aeruginosa ATCC 27853, Saccharomyces cerevisiae FAS 20 or Staphylococcus aureus ATCC 25923.

The type strain, MS405 ${ }^{\mathrm{T}}\left(=\mathrm{DSM} 41863^{\mathrm{T}}=\mathrm{CIP} 108995^{\mathrm{T}}\right)$, was isolated from a soil sample taken at the Durmitor National Park, Serbia and Montenegro.

\section{Acknowledgements}

This work was supported by grant 143056 from the Ministry of Science of the Republic of Serbia. We would like to thank Dr Graeme Conn for carefully reading and correcting the manuscript, Dr Aleksandra Korac for help with electron microscopy and Mr Dusan Misic and Lidija Djokic for help with physiological tests. We thank the DSMZ staff for their technical assistance with DNA relatedness analysis.

\section{References}

Altschul, S. F., Madden, T. L., Schaffer, A. A., Zhang, J., Zhang, Z., Miller, W. \& Lipman, D. J. (1997). Gapped BLAST and PSI-BLAST: a new generation of protein database search programs. Nucleic Acids Res 25, 3389-3402.

Atalan, E., Manfio, G. P., Ward, A. C., Kroppenstedt, R. M. \& Goodfellow, M. (2000). Biosystematic studies on novel streptomycetes from soil. Antonie van Leeuwenhoek 77, 337-353. 
Becker, B., Lechevalier, M. P. \& Lechevalier, H. A. (1965). Chemical composition of cell-wall preparations from strains of various formgenera of aerobic actinomycetes. Appl Microbiol 13, 236-243.

Chun, J., Youn, H. D., Yim, Y. I., Lee, H., Kim, M. Y., Hah, Y. C. \& Kang, S. O. (1997). Streptomyces seoulensis sp. nov. Int J Syst Bacteriol 47, 492-498.

De Ley, J., Cattoir, H. \& Reynaerts, A. (1970). The quantitative measurement of DNA hybridization from renaturation rates. Eur J Biochem 12, 133-142.

Elander, R. P. (1987). Microbial screening, selection and strain improvement. In Basic Biotechnology, pp. 217-251. Edited by J. Bu'Lock \& B. Kristiansen. London: Academic Press.

Felsenstein, J. (1985). Confidence limits on phylogenies: an approach using the bootstrap. Evolution 39, 783-791.

Felsenstein, J. (1993). PHYLIP (phylogenetic inference package), version 3.5c. Distributed by the author. Department of Genome Sciences, University of Washington, Seattle, USA.

Fitch, W. M. (1971). Toward defining the course of evolution: minimum change for a specific tree topology. Syst Zool 20, 406-416.

Gascuel, O. (1997). BIONJ: an improved version of the NJ algorithm based on a simple model of sequence data. Mol Biol Evol 14, 685-695.

Goodfellow, M., Manfio, G. P. \& Chun, J. (1997). Towards a practical species concept for cultivable bacteria. In Species: The Units of Diversity, pp. 25-29. Edited by M. F. Claridge, H. A. Dawah \& M. R. Wilson. London: Chapman \& Hall.

Gurtler, V. \& Stanisich, V. A. (1996). New approaches to typing and identification of bacteria using the $16 \mathrm{~S}-23 \mathrm{~S} \mathrm{rDNA}$ spacer region. Microbiology 142, 3-16.

Hain, T., Ward-Rainey, N., Kroppenstedt, R. M., Stackebrandt, E. \& Rainey, F. A. (1997). Discrimination of Streptomyces albidoflavus strains based on the size and number of 16S-23S ribosomal DNA intergenic spacers. Int J Syst Bacteriol 47, 202-206.

Hasegawa, T., Takizawa, M. \& Tanida, S. (1983). A rapid analysis for chemical grouping of aerobic actinomycetes. J Gen Appl Microbiol 29, 319-322.

Hopwood, D. A., Bibb, M. J., Chater, K. F., Kieser, T., Bruton, C. J., Kieser, H. M., Lydiate, C. P., Smith, C. P., Wards, J. M. \& Shrempf, H. (1985). Genetic Manipulation of Streptomyces: a Laboratory Manual. Norwich: John Innes Foundation.

Huß, V. A. R., Festl, H. \& Schleifer, K. H. (1983). Studies on the spectrophotometric determination of DNA hybridisation from renaturation rates. Syst Appl Microbiol 4, 184-192.

Jensen, M. A., Webster, A. J. \& Straus, N. (1993). Rapid identification of bacteria on the basis of polymerase chain reaction-amplified ribosomal DNA spacer polymorphisms. Appl Environ Microbiol 59, 945-952.

Kim, S. B., Falconer, C., Williams, E. \& Goodfellow, M. (1998). Streptomyces thermocarboxydovorans sp. nov. and Streptomyces thermocarboxydus sp. nov., two moderately thermophilic carboxydotrophic species from soil. Int J Syst Bacteriol 48, 59-68.

Kim, B., al-Tai, A. M., Kim, S. B., Somasundaram, P. \& Goodfellow, M. (2000). Streptomyces thermocoprophilus sp. nov., a cellulase-free endoxylanase-producing streptomycete. Int J Syst Evol Microbiol 50, 505-509.

Kimura, M. (1980). A simple method for estimating evolutionary rates of base substitutions through comparative studies of nucleotide sequences. J Mol Evol 16, 111-120.

Labeda, D. P. (1993). DNA relatedness among strains of the Streptomyces lavendulae phenotypic cluster group. Int $J$ Syst Bacteriol 43, 822-825.
Labeda, D. P. (1996). DNA relatedness among verticil-forming Streptomyces species (formerly Streptoverticillium species). Int J Syst Bacteriol 46, 699-703.

Labeda, D. P. (1998). DNA relatedness among the Streptomyces fulvissimus and Streptomyces griseoviridis phenotypic cluster groups. Int J Syst Bacteriol 48, 829-832.

Lane, D. J. (1991). 16S/23S rRNA sequencing. In: Nucleic Acid Techniques in Bacterial Systematics, pp. 115-175. Edited by E. Stackebrandt \& M. Goodfellow. Chichester: Wiley.

Lechevalier, M. P. \& Lechevalier, H. (1970). Chemical composition as a criterion in the classification of aerobic actinomycetes. Int J Syst Bacteriol 20, 435-443.

Maidak, B. L., Cole, J. R., Lilburn, T. G., Parker, C. T., Jr, Saxman, P. R., Farris, R. J., Garrity, G. M., Olsen, G. J., Schmidt, T. M. \& Tiedje, J. M. (2001). The RDP-II (Ribosomal Database Project). Nucleic Acids Res 29, 173-174.

Manfio, G. P., Atalan, E., Zakrewska-Czerwinska, J., Mordarski, M., Rodriguez, C., Collins, M. D. \& Goodfellow, M. (2003). Classification of novel soil streptomycetes as Streptomyces aureus sp. nov., Streptomyces laceyi sp. nov. and Streptomyces sanglieri sp. nov. Antonie van Leeuwenhoek 83, 245-255.

Marchesi, J. R., Sato, T., Weightman, A. J., Martin, T. A., Fry, J. C., Hiom, S. J., Dymock, D. \& Wade, W. G. (1998). Design and evaluation of useful bacterium-specific PCR primers that amplify genes coding for bacterial 16S rRNA. Appl Environ Microbiol 64, 795-799.

Mehling, A., Wehmeier, F. U. \& Piepersberg, W. (1995). Nucleotide sequences of streptomycete $16 \mathrm{~S}$ ribosomal DNA: towards a specific identification system for streptomycetes using PCR. Microbiology 141, 2139-2147.

Miller, J. H. (1992). A Short Course in Bacterial Genetics: a Laboratory Manual and Handbook for Escherichia coli and Related Bacteria. Cold Spring Harbor, NY: Cold Spring Harbor Laboratory.

O'Donnell, A. G., Falconer, C., Goodfellow, M., Ward, A. C. \& Williams, E. (1993). Biosystematics and diversity amongst novel carboxydotrophic Actinomycetes. Antonie van Leeuwenhoek 64, 325-340.

Rhuland, L. E., Work, E., Denman, R. F. \& Hoare, D. S. (1955). The behavior of the isomers of $\alpha, \varepsilon$-diaminopimelic acid on paper chromatograms. J Am Chem Soc 77, 4844-4846.

Saitou, N. \& Nei, M. (1987). The neighbor-joining method: a new method for reconstructing phylogenetic trees. Mol Biol Evol 4, 406-425.

Seeley, H. W., Jr \& VanDemark, P. J. (1981).. Microbes in Action. A Laboratory Manual of Microbiology, 3rd edn. San Francisco: W. H. Freeman.

Sembiring, L., Ward, A. C. \& Goodfellow, M. (2000). Selective isolation and characterisation of members of the Streptomyces violaceusniger clade associated with the roots of Paraserianthes falcataria. Antonie van Leeuwenhoek 78, 353-366.

Shirling, E. B. \& Gottlieb, D. (1966). Methods for characterization of Streptomyces species. Int J Syst Bacteriol 16, 313-340.

Skeggs, P. A., Thompson, J. \& Cundliffe, E. (1985). Methylation of 16S ribosomal RNA and resistance to aminoglycoside antibiotics in clones of Streptomyces lividans carrying DNA from Streptomyces tenjimaniensis. Mol Gen Genet 200, 415-421.

Skoko, N., Vujovic, J., Savic, M., Papic, N., Vasiljevic, B. \& Ljubijankic, G. (2005). Construction of Saccharomyces cerevisiae strain FAV20 useful in detection of immunosuppressants produced by soil actinomycetes. J Microbiol Methods 61, 137-140.

Song, J., Lee, S.-C., Kang, J.-W., Baek, H.-J. \& Suh, J.-W. (2004). Phylogenetic analysis of Streptomyces spp. isolated from potato scab lesions in Korea on the basis of 16S rRNA gene and 16S-23S rDNA 
intergenic transcribed spacer sequences. Int J Syst Evol Microbiol 54, 203-209.

Stackebrandt, E., Rainey, F. A. \& Ward-Rainey, N. L. (1997). Proposal for a new hierarchic classification system, Actinobacteria classis nov. Int J Syst Bacteriol 47, 479-491.

Thompson, J. D., Higgins, D. G. \& Gibson, T. J. (1994). CLUSTAL W: improving the sensitivity of progressive multiple sequence alignment through sequence weighting, position-specific gap penalties and weight matrix choice. Nucleic Acids Res 22, 4673-4680.

Umezawa, H., Ueda, M., Maeda, K., Yagishita, K., Kondo, S., Okami, Y., Utahara, R., Osato, Y., Nitta, K. \& Takeuchi, T. (1957). Production and isolation of a new antibiotic: kanamycin. J Antibiot (Tokyo) 10, 181-188.

Wayne, L. G., Brenner, D. J., Colwell, R. R., Grimont, P. A. D., Kandler, O., Krichevsky, M. I., Moore, L. H., Moore, W. E. C., Murray, R. G. E. \& other authors (1987). Report of the ad hoc committee on reconciliation of approaches to bacterial systematics. Int J Syst Bacteriol 37, 463-464.

Williams, S. T., Goodfellow, M., Alderson, G., Wellington, E. M. H., Sneath, P. H. A. \& Sackin, M. J. (1983). Numerical classification of Streptomyces and related genera. J Gen Microbiol 129, 1743-1813.

Woese, C. R. (1987). Bacterial evolution. Microbiol Rev 51, 221-271. 